\title{
Comparative Evaluation of Cytotoxicity of Neem Leaf Extract, $2 \%$ Chlorhexidine, Nigella sativa Extract and 3\% Sodium Hypochlorite
}

\author{
Vignesh Guptha Raju ${ }^{1}$, Shafie Ahamed A², Madhuram Krishnamurthy ${ }^{3}$, Selvendran KE ${ }^{4}$, Hamed Ahmed Ali Alshawkani ${ }^{5}$, \\ Omaima Ahmed Hassam Allayl ${ }^{6}$, Manar Ali Ibrahim Alhomood ${ }^{7}$, Mohammed Ali Ali Sumayli ${ }^{8}$, Shilpa Bhandi ${ }^{9}$
}

\begin{abstract}
To assess and compare the cytotoxicity of different root canal irrigants, namely $25 \%$ aqueous neem leaf extract (Azadirachta indica), $2 \%$ chlorhexidine (CHX), 25\% aqueous Nigella sativa extract (black seed) and 3\% sodium hypochlorite (NaOCl). Dulbecco modified Eagle's medium containing glutamine, fetal bovine serum, and antibiotics were used to culture human periodontal ligament cells. After trypsinization, $1 \times 10^{5}$ cell suspension was seeded in 24 well culture plates with $100 \mu \mathrm{L}$ of culture medium. Then $10 \mu \mathrm{l}$ of each irrigant was added to the wells, sealed, and incubated in an oven at $37^{\circ} \mathrm{C}$ in an atmosphere of $5 \% \mathrm{CO}_{2}$ and $95 \%$ humidity. Cytotoxicity was assessed at 1, 3, 6 , and 24 hours by evaluating the cell viability using the trypan blue assay. A microscope was used for counting viable cells and subjected to statistical analysis. $25 \%$ aqueous Neem leaf extract was the most cytotoxic irrigant tested, followed by $2 \%$ CHX, while $25 \%$ aqueous $N$. sativa extract was the least cytotoxic irrigant tested. $25 \%$ aqueous N. sativa extract and $3 \% \mathrm{NaOCl}$ solutions were significantly less toxic than $25 \%$ aqueous Neem leaf extract solution and cytotoxicity of $2 \%$ chlorhexidine was significantly more than $25 \%$ aqueous $\mathrm{N}$. sativa extract and $3 \% \mathrm{NaOCl}$ at all periods. Considering this encouraging in vitro data, herbal extracts could be an alternative root canal irrigant with the most negligible toxicity compared to conventional root canal irrigants, with undesirable effects.

Keywords: Cytotoxicity, Herbal irrigants, Nigella sativa.

World Journal of Dentistry (2022): 10.5005/jp-journals-10015-1894
\end{abstract}

\section{INTRODUCTION}

The success of endodontic therapy depends on thorough cleaning and shaping, with perfect three-dimensional fluid impervious obturation. One of the neglected phases of root canal therapy is proper irrigation and selection of an ideal irrigating solution. ${ }^{1}$ Mechanical instrumentation alone cannot provide a thorough and complete debridement of the root canal system, including all of its ramifications and anatomical irregularities. Therefore, irrigating solutions should be used in conjunction with endodontic preparation to eliminate microorganisms from the anatomical intricacies. ${ }^{2}$

Irrigation plays a significant role in endodontic treatment; in both vital and nonvital cases. Blunderbuss canals, perforations, and improper techniques can allow the solution to permeate into surrounding periodontal tissues. Irrigant extrusion occurs even in teeth with fully mature and intact apices. ${ }^{3}$ Therefore confinement of the irrigant to the root canal space is of paramount importance. Several irrigating solutions show cytotoxic potential; therefore, when choosing an endodontic irrigant, tissue cytotoxicity should be considered.

Sodium hypochlorite ( $\mathrm{NaOCl} 0.5-5.25 \%)$ is a widely used irrigant because it meets the majority of endodontic irrigant requirements better than any other known compound. The ability of $\mathrm{NaOCl}$ to dissolve necrotic tissue and organic components of the smear layer is unrivaled. ${ }^{4,5}$ However, it has some drawbacks, including high toxicity, an unpleasant taste, corrosive to instruments, inability to remove the inorganic portion of the smear layer, and a decrease in dentin's elastic modulus and flexural strength. ${ }^{6}$

2\% Chlorhexidine digluconate ( $\mathrm{CHX})$, a biguanide molecule, is another extensively used irrigant. It has extensive antibacterial activity and substantivity, however, it cannot dissolve the organic
${ }^{1}$ Department of Pediatric and Preventive Dentistry, Karpaga Vinayaga Institute of Dental Sciences, Chinnakolambakkam, Palayanoor Post, Maduranthagam Taluk, Chennai, Tamil Nadu, India

${ }^{2}$ Department of Conservative Dentistry \& Endodontics, Rajah Muthiah Dental College \& Hospital, Annamalai University, Annamalai Nagar, Cuddalore, Tamil Nadu, India

${ }^{3,4}$ Department of Conservative Dentistry \& Endodontics, Karpaga Vinayaga Institute of Dental Sciences, Chinnakolambakkam, Palayanoor Post, Maduranthagam Taluk, Chennai, Tamil Nadu, India

${ }^{5}$ Department of Restorative Dental Sciences, Division of Endodontics, College of Dentistry, Jazan University, Jazan, Saudi Arabia

${ }^{6,7}$ College of Dentistry, Jazan University, Jazan, Saudi Arabia

${ }^{8}$ Jazan Dental Center, Ministry of Health, Saudi Arabia

${ }^{9}$ Department of Restorative Dental Sciences, Division of Operative Dentistry, College of Dentistry, Jazan University, Jazan, Saudi Arabia

Corresponding Author: Shafie Ahamed A, Department of Conservative Dentistry \& Endodontics, Rajah Muthiah Dental College \& Hospital, Annamalai University, Annamalai Nagar, Cuddalore, Tamil Nadu, India, Phone: +91 9487442339, e-mail: speciality2001@yahoo.com

How to cite this article: Raju VG, Ahamed AS, Krishnamurthy M, et al. Comparative Evaluation of Cytotoxicity of Neem Leaf Extract, $2 \%$ Chlorhexidine, Nigella sativa Extract, and 3\% Sodium Hypochlorite. World J Dent 2022;13(1):46-52.

Source of support: Nil

Conflict of interest: None

substrate or necrotic tissue in the root canal system. ${ }^{4,5}$ Contact dermatitis, desquamative gingivitis, and tooth discoloration have all been documented as allergic reactions to $2 \% \mathrm{CHX} .^{5}$

(c) The Author(s). 2022 Open Access This article is distributed under the terms of the Creative Commons Attribution 4.0 International License (https://creativecommons.org/licenses/by-nc/4.0/), which permits unrestricted use, distribution, and non-commercial reproduction in anymedium, provided you give appropriate credit to the original author(s) and the source, provide a link to the Creative Commons license, and indicate ifchanges were made. The Creative Commons Public Domain Dedication waiver (http://creativecommons.org/publicdomain/zero/1.0/) applies to the data made available in this article, unless otherwise stated. 
The global scenario is now changing towards the use of herbal products in dentistry which has been termed as phytodentistry. Neem (Azadirachta indica) has been regarded as one of the most versatile medicinal herbs in India for over 2000 years, with a wide range of biological activities. Neem extract has recently been added to toothpaste and mouthwash. These agents have demonstrated a significant reduction in gingivitis and periodontitis by reducing the plaque levels. It has been reported that neem extract has antibacterial action against Streptococcus mutans, Enterococcus fecalis, and Candida albicans. Furthermore, it is readily available and economical. ${ }^{7}$

Nigella sativa (N. sativa, NS, Family Ranunculaceae) also called the black seed is a miracle herb with a plenteous historical and religious background, which has many chemical constituents; these phytochemical constituents of $N$. sativa seeds include amino acids, fatty acids, reducing sugars, mucilage, alkaloids, organic acids, tannins, resins, toxic glucoside, metarbin, bitter principles, glycosidal saponins, melanthin resembling helleborine, melanthigenin ash, moisture, and Arabic acid. ${ }^{8}$ Many pharmacologically active compounds have been isolated from black seeds, but the most reported active constituents are thymoquinone (TQ), dithymoquinone, thymol, and thymohydroquinone. The literature on the therapeutic potential of N. sativa in endodontics is scarce, but its miraculous powers are very tempting and need to be explored. Not much study has been performed to check the cytotoxicity of aqueous N. sativa extract. Hence this study aims to evaluate the toxic potency of $25 \%$ aqueous $N$. sativa extract and compare it with $25 \%$ aqueous Neem leaf extract, $2 \%$ chlorhexidine $(\mathrm{CHX})$ and $3 \%$ sodium hypochlorite as root canal irrigant.

\section{Materials and Methods}

\section{Preparation of Extracts}

\section{Preparation of 25\% Aqueous Neem Leaf Extract}

One hundred grams of Neem leaf powder was bought from IMPCOPS Chennai, India, and wrapped in a muslin fabric that had been soaked in $800 \mathrm{~mL}$ of distilled water in a beaker. To generate a $25 \%$ concentration of aqueous neem extract, the beaker was heated over a low flame until the extract was decreased to $400 \mathrm{~mL}$. After cooling, the extract was filtered using Whatman filter paper no. 1 and kept in an amber bottle.

\section{Preparation of $25 \%$ Aqueous N. sativa Extract}

$N$. sativa seed powder was obtained from IMPCOPS Chennai, India. Two hundred fifty grams powder was mixed with $1000 \mathrm{~mL}$ distilled water, vortexed until no more color change occurred, and the solution was left at $4^{\circ} \mathrm{C}$ for 24 hours in a sterile tube. This was centrifuged for 15 minutes at $3000 \mathrm{rpm}$, and the supernatant (brownish-orange in color) was filtered through Whatman filter paper no. 4 and kept at $4^{\circ} \mathrm{C}$ in sterile tubes until use. ${ }^{9}$

The study protocol was approved by the ethical committee of Karpaga Vinayaga Institute of Dental Sciences (IRB NO: KIDS/IRB/3-2020/019). The human periodontal ligament fibroblasts used to test the cytotoxicity of irrigating solutions were obtained from periodontal ligament cells of maxillary premolars, which were extracted for orthodontic reasons. Periodontal ligament was carefully removed from the middle part of the root to avoid contamination by the gingiva. The cells were cultured sterile in $75 \mathrm{~cm}^{2}$ flasks containing $30 \mathrm{~mL}$ of Dulbecco modified Eagle's medium (DMEM) with glutamine and $10 \%$ inactivated fetal bovine serum (FBS), $50 \mu \mathrm{g} / \mathrm{mL}$ streptomycin and $3 \mu \mathrm{g} / \mathrm{mL}$ amphotericin.
The culture medium was replaced every 2-3 days during the cell culture procedure, and cells were passaged after one week. Cells obtained sufficient confluence for cytotoxicity tests after four passes. The cells were plated into $60 \mathrm{~mm}$ culture dishes and maintained at $37^{\circ} \mathrm{C}$ in a $5 \% \mathrm{CO}_{2}$ and $95 \%$ humidity atmosphere until they reached confluence and were withdrawn from the culture medium. After a 5-minute wash with fetal bovine serum (FBS) and ethylenediamine tetraacetic acid (EDTA), the cells were trypsinized by removing this solution and agitating until cells separated.

\section{Treatment with Irrigants}

\section{Experimental Groups}

- Group 1:25\% Aqueous neem leaf extract

- Group 2:2\% Chlorhexidine

- Group 3: $25 \%$ Aqueous N. sativa extract

- Group 4: 3\% Sodium hypochlorite

- Group 5: Control-Culture medium (Dulbecco modified Eagle's medium)

Centrifugation at $250 \mathrm{rpm}$ for 5 minutes after trypsinization was used to collect specimens and cell groups were distributed in Dulbecco modified Eagle's medium (DMEM) and 10\% fetal bovine serum (FBS) culture medium. During the fibroblast growth process, the cell count was initially determined on the third day and thereafter daily. Trypsin was administered to float fibroblasts; the solution was then drawn and placed in a test tube. After that, the test tube was centrifuged for 10 minutes at an RPM range of 800-1000. After centrifuging the sediment once more, the finished solution was deposited in the Neubauer chamber. The cell suspension was counted using a Neubauer counting chamber under a microscope ( $20 \mu \mathrm{l}$ of suspension contained $1 \times 10^{5}$ cells).

In the 24 well culture plate, the wells were arranged in six rows and four columns, in which five rows were used for depicting five experimental groups and four columns were used for representing four-time periods ( $1,3,6$, and 24 hours). $20 \mu \mathrm{l}$ of suspension was taken from the culture dish with a multichannel micropipette and seeded in 24-well culture plates with $100 \mu$ of culture medium for 48 hours in an oven at $37^{\circ} \mathrm{C}$ in $5 \% \mathrm{CO}_{2}$ and $95 \%$ humidity atmosphere.

A multichannel pipette was used to remove $10 \mu \mathrm{l}$ of aqueous neem leaf extract and was added to the four-time period wells in the Group 1 of the well culture plate. $10 \mu$ l of $2 \%$ chlorhexidine was added to the four-time period wells in the Group 2 of the well culture plate. $10 \mu \mathrm{l}$ of $25 \%$ aqueous solution of $N$. sativa extract was added to the four-time period wells in the Group 3 of the well culture plate. $10 \mu \mathrm{l}$ of $3 \%$ sodium hypochlorite was added to the four-time period wells in the Group 4 of the well culture plate. No irrigant was added in the control group, which was Group 5. Plates were then sealed and placed in an oven at $37^{\circ} \mathrm{C}$ in an atmosphere of $5 \% \mathrm{CO}_{2}$ and $95 \%$ humidity. Culture plates were always handled in sterile conditions under a Laminar Flow Hood, and sterile multichannel pipette tips were used, which were disposed of on every use to avoid bacterial contamination.

\section{Cytotoxicity Test}

Cytotoxicity of irrigating solutions was assessed at 1, 3, 6, and 24 hours after incubation, evaluating the cell viability by using Trypan blue assay.

Trypan blue is a vital stain that is used to color dead tissues or cells blue in a selective manner. It is a type of diazo dye. Color is not added to live cells or tissues with intact cell membranes 
because cells are selective about the substances that pass through their membranes. Trypan blue is not absorbed in a healthy cell; nevertheless, it does pass past the membrane in a dead cell. Thus, dead cells appear as a distinct blue color when viewed via a microscope. Since live cells are not stained, this staining approach is sometimes referred to as a dye exclusion method.

At the end of one hour, the 24 well culture plates were taken out of the incubator, the cells were taken from the one hour wells from all the groups respectively with a multichannel micropipette into an Eppendorf tube $(1.5 \mathrm{~mL})$ and $0.4 \%$ Trypan blue dye was added, mixed gently and allowed to stand for five minutes in room temperature. $10 \mu \mathrm{l}$ of the stained cells were placed on the Neubauer counting chamber covered with a coverslip and placed on the microscope. The number of viable cells (unstained cells) and the dead cells (stained cells) were counted, and the percentage of viable cells was obtained; this was followed in all groups in 3, 6, and 24 hours, respectively. More number of viable cells at any period implies that the irrigant is less cytotoxic and less number of viable cells indicates that the irrigant is more cytotoxic.

Total number of cells $=$ Total number of viable cells + Total number of dead cells.

\section{Statistical Analysis}

Statistical comparison between the groups was made by one-way ANOVA followed by post hoc comparison between groups with
Bonferroni correction with a significance level of 0.05. Comparison within a time interval of all groups using repeated-measures ANOVA followed by post hoc comparison within a time interval of all groups with Bonferroni correction. Data were analyzed using the SPSS 21 package.

\section{Results}

Comparison between groups - Table 1 represents the overall comparison of mean values of percentage of cell viability between the groups. Table 2 represents a post hoc comparison between two groups at different time intervals.

\section{At 1-hour Time Interval (Fig. 1)}

Cytotoxicity of Neem leaf extract ( $A$. indica) in one hour was significantly more toxic than $25 \% \mathrm{~N}$. sativa extract, $3 \% \mathrm{NaOCl}$ and control group but not statistically significant to $2 \% \mathrm{CHX} ; 2 \% \mathrm{CHX}$ was significantly more toxic than $25 \% \mathrm{~N}$. sativa extract, $3 \% \mathrm{NaOCl}$ and control group. There was no statistically significant difference in the cytotoxicity of $25 \% \mathrm{~N}$. sativa extract, $3 \% \mathrm{NaOCl}$, and Control groups. However, their cytotoxicity was significantly less than $2 \%$ $\mathrm{CHX}$ and Neem extract. Summarizing the results of all the groups at the end of one hour.

\section{At 3-hour Time Interval (Fig. 2)}

The cytotoxicity of Neem leaf extract in three hours was statistically not significant when compared to $2 \% \mathrm{CHX}$. The cytotoxicity of $2 \%$

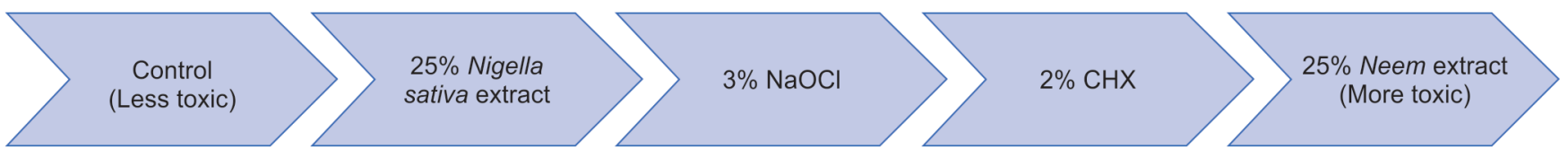

Fig 1: At 1-hour time interval

Table 1: Comparison between groups using one-way ANOVA

\begin{tabular}{|c|c|c|c|c|c|c|c|c|c|c|}
\hline \multirow[b]{2}{*}{ Time interval } & \multirow[b]{2}{*}{ Groups } & \multirow[b]{2}{*}{ Mean } & \multirow[b]{2}{*}{ S.D. } & \multirow[b]{2}{*}{ Std. error } & \multicolumn{2}{|c|}{$95 \%$ confidence interval for mean } & \multirow[b]{2}{*}{ Minimum } & \multirow[b]{2}{*}{ Maximum } & \multirow[b]{2}{*}{$F$} & \multirow[b]{2}{*}{$p$-value } \\
\hline & & & & & Lower bound & Upper bound & & & & \\
\hline \multirow[t]{5}{*}{1 hour } & 1 & 71.20 & 2.46 & 0.63 & 69.84 & 72.56 & 68.00 & 75.00 & 62.995 & $0.001^{* *}$ \\
\hline & 2 & 72.47 & 3.60 & 0.93 & 70.47 & 74.46 & 67.00 & 79.00 & & \\
\hline & 3 & 80.13 & 1.60 & 0.41 & 79.25 & 81.02 & 78.00 & 83.00 & & \\
\hline & 4 & 80.00 & 1.00 & 0.26 & 79.45 & 80.55 & 78.00 & 82.00 & & \\
\hline & 5 & 80.80 & 1.86 & 0.48 & 79.77 & 81.83 & 78.00 & 84.00 & & \\
\hline \multirow[t]{5}{*}{3 hours } & 1 & 74.07 & 2.22 & 0.57 & 72.84 & 75.30 & 70.00 & 78.00 & 34.689 & $0.001^{* *}$ \\
\hline & 2 & 74.73 & 3.83 & 0.99 & 72.61 & 76.85 & 69.00 & 80.00 & & \\
\hline & 3 & 81.60 & 1.45 & 0.38 & 80.79 & 82.41 & 79.00 & 84.00 & & \\
\hline & 4 & 80.87 & 1.60 & 0.41 & 79.98 & 81.75 & 78.00 & 84.00 & & \\
\hline & 5 & 81.40 & 2.61 & 0.68 & 79.95 & 82.85 & 76.00 & 86.00 & & \\
\hline \multirow[t]{5}{*}{6 hours } & 1 & 74.73 & 3.69 & 0.95 & 72.69 & 76.78 & 69.00 & 80.00 & 27.488 & $0.001^{* *}$ \\
\hline & 2 & 76.93 & 3.79 & 0.98 & 74.84 & 79.03 & 70.00 & 82.00 & & \\
\hline & 3 & 83.33 & 1.50 & 0.39 & 82.50 & 84.16 & 80.00 & 86.00 & & \\
\hline & 4 & 82.33 & 1.80 & 0.47 & 81.34 & 83.33 & 80.00 & 86.00 & & \\
\hline & 5 & 81.93 & 2.37 & 0.61 & 80.62 & 83.25 & 78.00 & 86.00 & & \\
\hline \multirow[t]{5}{*}{24 hours } & 1 & 77.67 & 5.42 & 1.40 & 74.66 & 80.67 & 68.00 & 84.00 & 14.93 & $0.001^{* *}$ \\
\hline & 2 & 79.93 & 5.23 & 1.35 & 77.04 & 82.83 & 71.00 & 88.00 & & \\
\hline & 3 & 86.93 & 1.49 & 0.38 & 86.11 & 87.76 & 84.00 & 89.00 & & \\
\hline & 4 & 85.07 & 2.15 & 0.56 & 83.87 & 86.26 & 81.00 & 88.00 & & \\
\hline & 5 & 86.47 & 4.85 & 1.25 & 83.78 & 89.15 & 80.00 & 96.00 & & \\
\hline
\end{tabular}

${ }^{*} p$ value $<0.05$ statistically significant

${ }^{* *} p$ value $<0.001$ highly significant 
Table 2: Post hoc comparison between groups with Bonferroni correction

\begin{tabular}{|c|c|c|c|c|c|c|c|c|c|}
\hline \multirow{2}{*}{$\begin{array}{l}\text { Time interval } \\
1 \text { hour }\end{array}$} & \multicolumn{2}{|c|}{ Groups } & \multirow{2}{*}{$\begin{array}{c}\text { Mean difference } \\
-1.267\end{array}$} & \multirow{2}{*}{$\frac{p \text {-value }}{0.133}$} & \multirow{2}{*}{$\begin{array}{l}\text { Time interval } \\
6 \text { hours }\end{array}$} & \multicolumn{2}{|c|}{ Groups } & \multirow{2}{*}{$\begin{array}{c}\text { Mean difference } \\
-2.200^{*}\end{array}$} & \multirow{2}{*}{$\frac{p \text {-value }}{0.035}$} \\
\hline & 1 & 2 & & & & 1 & 2 & & \\
\hline & 1 & 3 & $-8.933^{*}$ & 0.001 & & 1 & 3 & $-8.600^{*}$ & 0.001 \\
\hline & 1 & 4 & $-8.800^{*}$ & 0.001 & & 1 & 4 & $-7.600^{*}$ & 0.001 \\
\hline & 1 & 5 & $-9.600^{*}$ & 0.001 & & 1 & 5 & $-7.200^{*}$ & 0.001 \\
\hline & 2 & 3 & $-7.667^{*}$ & 0.001 & & 2 & 3 & $-6.400^{*}$ & 0.001 \\
\hline & 2 & 4 & $-7.533^{*}$ & 0.001 & & 2 & 4 & $-5.400^{*}$ & 0.001 \\
\hline & 2 & 5 & $-8.333^{*}$ & 0.001 & & 2 & 5 & $-5.000^{*}$ & 0.001 \\
\hline & 3 & 4 & 0.133 & 0.873 & & 3 & 4 & 1 & 0.331 \\
\hline & 3 & 5 & -0.667 & 0.426 & & 3 & 5 & 1.4 & 0.175 \\
\hline & 4 & 5 & -0.8 & 0.34 & & 4 & 5 & 0.4 & 0.696 \\
\hline \multirow[t]{10}{*}{3 hours } & 1 & 2 & -0.667 & 0.466 & 24 hours & 1 & 2 & -2.267 & 0.142 \\
\hline & 1 & 3 & $-7.533^{*}$ & 0.001 & & 1 & 3 & $-9.267^{*}$ & 0.001 \\
\hline & 1 & 4 & $-6.800^{*}$ & 0.001 & & 1 & 4 & $-7.400^{*}$ & 0.001 \\
\hline & 1 & 5 & $-7.333^{*}$ & 0.001 & & 1 & 5 & $-8.800^{*}$ & 0.001 \\
\hline & 2 & 3 & $-6.867^{*}$ & 0.001 & & 2 & 3 & $-7.000^{*}$ & 0.001 \\
\hline & 2 & 4 & $-6.133^{*}$ & 0.001 & & 2 & 4 & $-5.133^{*}$ & 0.001 \\
\hline & 2 & 5 & $-6.667^{*}$ & 0.001 & & 2 & 5 & $-6.533^{*}$ & 0 \\
\hline & 3 & 4 & 0.733 & 0.423 & & 3 & 4 & 1.867 & 0.225 \\
\hline & 3 & 5 & 0.2 & 0.827 & & 3 & 5 & 0.467 & 0.76 \\
\hline & 4 & 5 & -0.533 & 0.56 & & 4 & 5 & -1.4 & 0.362 \\
\hline
\end{tabular}

${ }^{*} p$ value $<0.05$ statistically significant

** $p$ value $<0.001$ highly significant

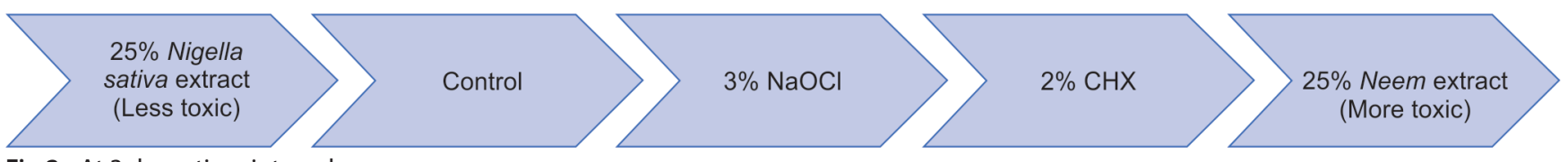

Fig 2: At 3 -hour time interval

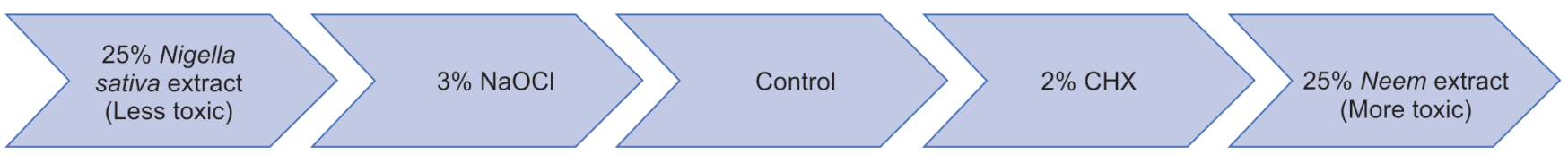

Fig 3: At 6 -hour time interval

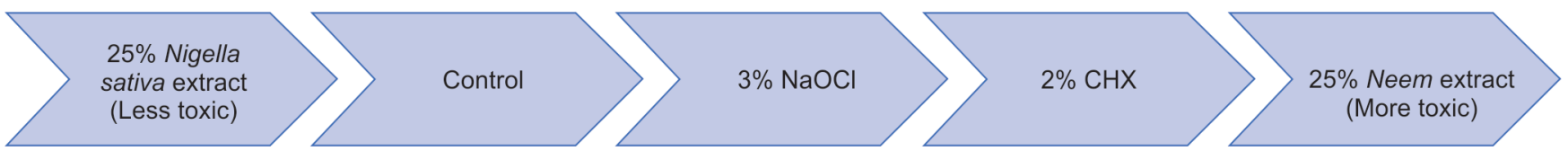

Fig 4: At 24 -hour time interval

$\mathrm{CHX}$ was more when compared to $25 \%$ N. sativa extract, $3 \% \mathrm{NaOCl}$, and statistically significant control groups. $25 \%$ N. sativa extract, $3 \%$ $\mathrm{NaOCl}$, and control groups were significantly less toxic than $25 \%$ Neem leaf extract. Summarizing the results of all the groups at the end of three hours.

\section{At 6-hour Time Interval (Fig. 3)}

Cytotoxicity of $25 \%$ Neem leaf extract in six hours was significantly more than all the other groups; $2 \% \mathrm{CHX}$ was significantly more toxic than all the other groups except neem extract; the cytotoxicity of $25 \% \mathrm{~N}$. sativa extract, $3 \% \mathrm{NaOCl}$ and control was not statistically significant. However, their cytotoxicity was significantly less than $2 \%$ $\mathrm{CHX}$ and Neem leaf extract. Summarizing the results of all the groups at the end of six hours.

\section{At 24-hour Time Interval (Fig. 4)}

Cytotoxicity of $25 \%$ Neem leaf extract in 24 hours was significantly more toxic than $25 \% \mathrm{~N}$. sativa extract, $3 \% \mathrm{NaOCl}$, and control groups. $2 \% \mathrm{CHX}$ was significantly more toxic than all the other groups except Neem leaf extract. Comparing cytotoxicity between the groups of $25 \% \mathrm{~N}$. sativa extract, $3 \% \mathrm{NaOCl}$, and control was not statistically significant. However, their cytotoxicity was significantly less than $2 \%$ CHX and 25\% Neem leaf extract; Summarizing the results of all the groups at the end of 24 hours.

\section{Within Groups Comparison}

Table 3 represents the overall comparison within a time interval of all groups. Table 4 represents the post hoc comparison within 
Table 3: Comparison with time interval of all groups using repeated measures ANOVA

\begin{tabular}{llllll}
\hline Groups & $\begin{array}{l}\text { Type III sum of } \\
\text { squares }\end{array}$ & $d f$ & Mean square & S & Sig. \\
\hline 1 & 316.983 & 2.015 & 157.276 & 9.507 & 0.001 \\
2 & 456.45 & 1.715 & 266.16 & 57.936 & 0.001 \\
3 & 386.4 & 2.384 & 162.051 & 72.032 & 0.001 \\
4 & 221.733 & 2.189 & 101.278 & 40.438 & 0.001 \\
5 & 300.983 & 2.008 & 149.881 & 11.411 & 0.001 \\
\hline
\end{tabular}

${ }^{*} p$ value $<0.05$ statistically significant

${ }^{* *} p$ value $<0.001$ highly significant

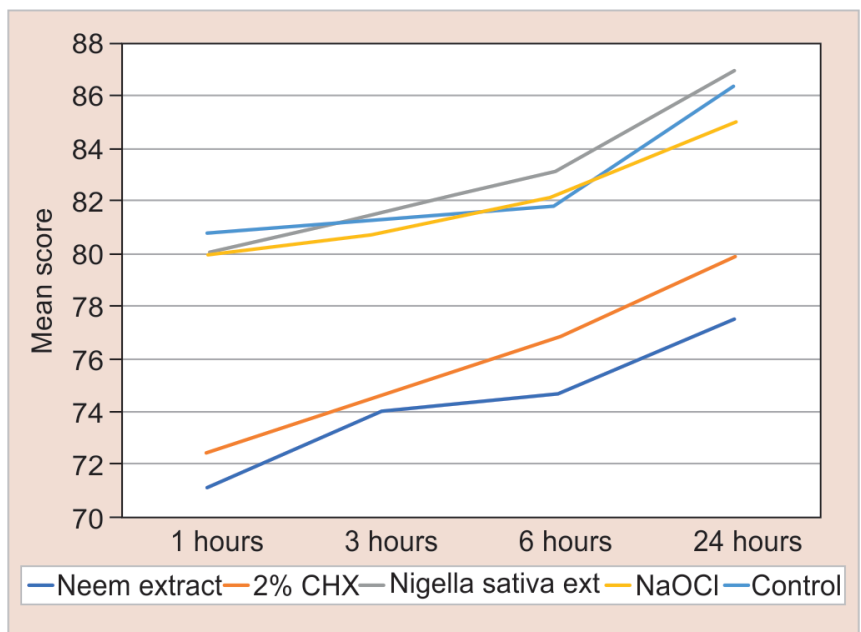

Fig. 5: Mean comparison between and within groups at different time intervals

time intervals of different groups. Figure 5 represents the mean comparison between and within groups at different time intervals. Cytotoxicity of all groups significantly decreased over the periodall materials changing in time-bound.

\section{Discussion}

The endodontic irrigating solution should act as an antimicrobial agent but with low periapical tissue toxicity. ${ }^{10}$ Endodontic material biocompatibility is determined by several factors, including cytotoxicity, histocompatibility, genotoxicity, mutagenicity, carcinogenicity, and microbial impact. These properties must be explored using a structured battery of various in vitro and in vivo studies. Any newly discovered material should undergo three distinct levels of testing, ranging from simple to complex test methods, in vitro to animal testing, and pre-clinical to clinical testing on people. ${ }^{11}$ Since $N$. sativa and neem leaf extracts are being evaluated as root canal irrigants, this study was conducted to determine their cytotoxicity in comparison to traditional root canal irrigants such as sodium hypochlorite and chlorhexidine. The cytotoxicity of neem leaf extract against human periodontal ligament cells was determined in this study utilizing the Trypan blue assay. The results of the study show that the cytotoxicity of the aqueous neem leaf extract was significantly reduced from 1 to 24 hours. $25 \%$ of aqueous neem leaf extract has shown higher toxicity than $2 \%$ chlorhexidine, $25 \%$ aqueous $N$. sativa extract, and $3 \%$ Sodium hypochlorite. This could be due to the higher concentration of neem leaf extract that has been evaluated.
The results of the present study show that cytotoxicity of Group-2 ( $2 \%$ chlorhexidine) is significantly more than Groups 3, 4, and 5 (25\% aqueous N. sativa extract, $3 \%$ sodium hypochlorite, and control, respectively) at the different periods studied. Fernenda Campos et al. evaluated the cytotoxicity of chlorhexidine at various concentrations $(0.06 \%, 0.12 \%, 0.2 \%, 1 \%$, and $2 \%$ ) on odontoblast-like cells and found that $2 \%$ was the most toxic. Increased toxicity to cells was observed as the chlorhexidine concentration was increased (from 0.06 to $2 \%$ ), indicating that chlorhexidine has a dose-dependent toxic effect. Additionally, the toxicity was directly proportional to the duration of exposure. ${ }^{12}$ The above finding was also supported by the animal study done by Gisele Faria et al. Their findings showed that chlorhexidine injected in the subplantar space of the hind paw of mice caused severe necrotic changes in the epidermis, dermis, and the subcutaneous tissue at 24 and 48 hours. At the end of 7 and 14 days, the tissue healing was complete. ${ }^{13}$

The use of $3 \% \mathrm{NaOCl}$ for biomechanical preparation of root canals is a clinically acceptable and highly effective procedure. Previous studies have shown that the antibacterial property of sodium hypochlorite depends on the availability of hypochlorous acid. When the $\mathrm{pH}$ reduces, sodium hypochlorite dissociates, and all the available chlorine is in the form of hypochlorous acid. ${ }^{5}$ Winter et al. investigated the intracellular effect of hypochlorous acid and demonstrated that it leads to cellular protein aggregation and unfolding, which is responsible for its cytotoxicity. ${ }^{14}$ Eduard Hidalgo et al. investigated the bactericidal effectiveness and cytotoxicity of sodium hypochlorite. They explained cytotoxicity 
Comparison of Cytotoxicity of Herbal and Nonherbal Endodontic Irrigants

Table 4 Post hoc comparison within time interval of all groups with Bonferronic correction

\begin{tabular}{|c|c|c|c|c|c|c|c|}
\hline \multirow[b]{2}{*}{ Groups } & \multirow[b]{2}{*}{ Time interval $A$} & \multirow[b]{2}{*}{ Time interval $B$} & \multirow[b]{2}{*}{ Mean difference } & \multirow[b]{2}{*}{ Std. error } & \multirow[b]{2}{*}{$p$ value } & \multicolumn{2}{|c|}{ 95\% confidence interval for difference } \\
\hline & & & & & & Lower bound & Upper bound \\
\hline \multirow[t]{6}{*}{1} & 1 hour & 3 hours & $-2.867^{*}$ & 0.401 & 0.001 & -3.726 & -2.007 \\
\hline & 1 hour & 6 hours & $-3.533^{*}$ & 1.272 & 0.015 & -6.261 & -0.805 \\
\hline & 1 hour & 24 hours & $-6.467^{*}$ & 1.427 & 0.001 & -9.528 & -3.406 \\
\hline & 3 hours & 6 hours & -0.667 & 1.149 & 0.571 & -3.131 & 1.798 \\
\hline & 3 hours & 24 hours & $-3.600^{*}$ & 1.403 & 0.022 & -6.61 & -0.59 \\
\hline & 6 hours & 24 hours & $-2.933^{*}$ & 1.336 & 0.045 & -5.799 & -0.067 \\
\hline \multirow[t]{6}{*}{2} & 1 hour & 3 hours & $-2.267^{*}$ & 0.284 & 0.001 & -2.876 & -1.658 \\
\hline & 1 hour & 6 hours & $-4.467^{*}$ & 0.477 & 0.001 & -5.489 & -3.444 \\
\hline & 1 hour & 24 hours & $-7.467^{*}$ & 0.822 & 0.001 & -9.229 & -5.705 \\
\hline & 3 hours & 6 hours & $-2.200^{*}$ & 0.416 & 0.001 & -3.093 & -1.307 \\
\hline & 3 hours & 24 hours & $-5.200^{*}$ & 0.685 & 0.001 & -6.668 & -3.732 \\
\hline & 6 hours & 24 hours & $-3.000^{*}$ & 0.69 & 0.001 & -4.48 & -1.52 \\
\hline \multirow[t]{6}{*}{3} & 1 hour & 3 hours & $-1.467^{*}$ & 0.376 & 0.002 & -2.274 & -0.66 \\
\hline & 1 hour & 6 hours & $-3.200^{*}$ & 0.428 & 0.001 & -4.117 & -2.283 \\
\hline & 1 hour & 24 hours & $-6.800^{*}$ & 0.536 & 0.001 & -7.95 & -5.65 \\
\hline & 3 hours & 6 hours & $-1.733^{*}$ & 0.384 & 0.001 & -2.557 & -0.91 \\
\hline & 3 hours & 24 hours & $-5.333^{*}$ & 0.583 & 0.001 & -6.583 & -4.083 \\
\hline & 6 hours & 24 hours & $-3.600^{*}$ & 0.576 & 0.001 & -4.835 & -2.365 \\
\hline \multirow[t]{6}{*}{4} & 1 hour & 3 hours & $-0.867^{*}$ & 0.401 & 0.048 & -1.726 & -0.007 \\
\hline & 1 hour & 6 hours & $-2.333^{*}$ & 0.374 & 0.001 & -3.135 & -1.532 \\
\hline & 1 hour & 24 hours & $-5.067^{*}$ & 0.483 & 0.001 & -6.102 & -4.031 \\
\hline & 3 hours & 6 hours & $-1.467^{*}$ & 0.424 & 0.004 & -2.376 & -0.558 \\
\hline & 3 hours & 24 hours & $-4.200^{*}$ & 0.649 & 0.001 & -5.592 & -2.808 \\
\hline & 6 hours & 24 hours & $-2.733^{*}$ & 0.573 & 0.001 & -3.962 & -1.505 \\
\hline \multirow[t]{6}{*}{5} & 1 hour & 3 hours & -0.6 & 0.975 & 0.548 & -2.691 & 1.491 \\
\hline & 1 hour & 6 hours & -1.133 & 0.92 & 0.238 & -3.106 & 0.84 \\
\hline & 1 hour & 24 hours & $-5.667^{*}$ & 1.275 & 0.001 & -8.401 & -2.932 \\
\hline & 3 hours & 6 hours & -0.533 & 0.533 & 0.334 & -1.677 & 0.611 \\
\hline & 3 hours & 24 hours & $-5.067^{*}$ & 1.406 & 0.003 & -8.082 & -2.052 \\
\hline & 6 hours & 24 hours & $-4.533^{*}$ & 1.162 & 0.002 & -7.026 & -2.04 \\
\hline
\end{tabular}

${ }^{*} p$ value $<0.05$ statistically significant

${ }^{* *} p$ value $<0.001$ highly significant

mechanism of sodium hypochlorite lies in the fact that neither bacteria nor human cells can counteract the cytotoxic effect of hypochlorous acid since they lack the enzyme required for its catalytic detoxification. ${ }^{15}$ As the antimicrobial effect increases with more available hypochlorous acid, the cytotoxicity also increases. ${ }^{5}$ This hypothesis has been proven by Virginie Aubut et al., where they evaluated the cytotoxicity of neutralized $2.5 \%$ sodium hypochlorite. This neutralized solution was 10 -fold more toxic than its unbuffered counterpart. ${ }^{14}$

Results of our study showed $25 \%$ aqueous $N$. sativa extract is significantly less cytotoxic than $2 \% \mathrm{CHX}$ and $25 \%$ aqueous neem leaf extract at all tested periods. The seed extract and its constituents appear to have a low level of toxicity. A study done by El Daly 1998 shows five days of intraperitoneal treatment of $N$. sativa seed extract $(50 \mathrm{mg} / \mathrm{kg}$ ) to rats had no significant effect on the activity of numerous enzymes and metabolites indicative of hepatic and renal function. ${ }^{16}$ During a 48-hour observation period, oral administration of $N$. sativa seed oil at doses up to $10 \mathrm{ml} / \mathrm{kg}$ caused no mortality or overt toxicity in rats and mice. ${ }^{17}$ The therapeutic effects of utilizing seeds and thymoquinone appear to be related to their cytoprotective and antioxidant properties, as well as their effect on certain inflammatory mediators. ${ }^{18}$

\section{Limitations}

In vitro screening tests such as the cytotoxicity assay are critical for deciphering the fundamental effects of dental materials. However, the methodology has a limitation in that it does not simulate the clinical condition. As a result, it is implausible to extrapolate the in vitro findings to the in vivo situation. However, a comparable interpretation of the in vitro toxicity data provides valuable information about the materials' overall toxic potential.

\section{ConcLusion}

Within the limitations of the present study, the following conclusions were made, the cytotoxicity of all the irrigants significantly reduced from 1 to 24 hours of the observation period. $25 \%$ aqueous $N$. sativa extract and $3 \% \mathrm{NaOCl}$ solutions were significantly less toxic than $25 \%$ aqueous Neem leaf extract solution at all periods. Cytotoxicity of $2 \%$ chlorhexidine was significantly more than $25 \%$ 
aqueous $N$. sativa extract and $3 \% \mathrm{NaOCl}$. $25 \%$ aqueous neem extract was not significantly different from $2 \%$ chlorhexidine except at 6 hours. The cytotoxicity of the control group was not statistically significant from $25 \%$ aqueous N. sativa extract and $3 \% \mathrm{NaOCl}$.

\section{Clinical Significance}

Since irrigating solutions can contact surrounding soft and hard tissues during endodontic treatment, they should have acceptable biocompatibility. Therefore, biocompatibility data of these herbal root canal irrigants concerning cytotoxicity are needed for complete risk assessment before considering it as a choice of irrigation solution.

\section{References}

1. Chandra S. Grossman's Endodontic Practice. Wolters Kluwer (India) 2014. https://books.google.co.in/books?id=tC3vDwAAQBAJ

2. Gernhardt CR, Eppendorf K, Kozlowski A, et al. Toxicity of concentrated sodium hypochlorite used as an endodontic irrigant. Int Endod J 2004;37(4):272-280. DOI: 10.1111/j.0143-2885.2004.00804.x

3. Salzgeber RM, Brilliant JD. An in vivo evaluation of the penetration of an irrigating solution in root canals. J Endod 1977;3(10):394-398. DOI: 10.1016/S0099-2399(77)80172-6

4. Zehnder M. Root canal irrigants. J Endod 2006;32(5):389-398. DOI: 10.1016/j.joen.2005.09.014

5. Kandaswamy D, Venkateshbabu N. Root canal irrigants. J Conserv Dent 2010;13(4):256-264. DOI: 10.4103/0972-0707.73378

6. Pujar M, Patil CKA. Comparison of antimicrobial efficacy of Triphala, (GTP) green tea polyphenols and 3\% of sodium hypochlorite onbiofilms formed on tooth substrate: in vitro Enterococcus faecalis. J Int Oral Heal 2011;3(2). DOI: 10.1016/j.joen.2009.09.040

7. Bohora A, Hegde V, Kokate S. Comparison of the antibacterial efficiency of neem leaf extract and $2 \%$ sodium hypochlorite against, and mixed culture - an in vitro study E. faecalisC. albicans. Endodontology 2009;22.
8. Ahmad A, Husain A, Mujeeb $M$, et al. A review on therapeutic potential of: a miracle herb Nigella sativa. Asian Pac J Trop Biomed 2013;3(5):337-352. DOI: 10.1016/S2221-1691(13)60075-1

9. Khodair A I HFA, A-AH. Phytochemical investigation of thymus de cassatus. Qutar Univ Sci J 1993;13(12):211-213.

10. Chang YC, Huang FM, Tai KW, et al. The effect of sodium hypochlorite and chlorhexidine on cultured human periodontal ligament cells. Oral Surg Oral Med Oral Pathol Oral Radiol Endod 2001;92(4):446-450. DOI: 10.1067/moe.2001.116812

11. Hauman CHJ, Love RM. Biocompatibility of dental materials used in contemporary endodontic therapy: a review. Part 1. Intracanal drugs and substances. Int Endod J 2003;36(2):75-85. DOI: 10.1046/j.13652591.2003.00631.x

12. Lessa FCR, Aranha AMF, Nogueira I, et al. Toxicity of chlorhexidine on odontoblast-like cells. J Appl Oral Sci 2010;18(1):50-58. DOI: 10.1590/s1678-77572010000100010

13. Faria G, Celes MRN, De Rossi A, et al. Evaluation of chlorhexidine toxicity injected in the paw of mice and added to cultured 1929 fibroblasts. J Endod 2007;33(6):715-722. DOI: 10.1016/j. joen.2006.12.023

14. Aubut V, Pommel L, Verhille B, et al. Biological properties of a neutralized $2.5 \%$ sodium hypochlorite solution. Oral Surg Oral Med Oral Pathol Oral Radiol Endod 2010;109(2):e120-e125. DOI: 10.1016/j. tripleo.2009.09.022

15. Hidalgo E, Bartolome R, Dominguez C. Cytotoxicity mechanisms of sodium hypochlorite in cultured human dermal fibroblasts and its bactericidal effectiveness. Chem Biol Interact 2002;139(3):265282. DOI: 10.1016/s0009-2797(02)00003-0

16. el Daly ES. Protective effect of cysteine and vitamin E, Crocus sativus andextracts on cisplatin-induced toxicity in rats Nigella sativa. J Pharm Belg 1998;53(2):87-93; (Discussion 93-5). http://www.ncbi. nlm.nih.gov/pubmed/9609969

17. Khanna T, Zaidi FA, Dandiya P. CNS and analgesic studies on Nigella sativa. Fitoterapia 1993;64:407-410.

18. Ali B, Blunden G. Pharmacological and toxicological properties of Nigella sativa. Phytother Res. 2003;17:299-305. DOI:10.1002/ptr.1309 